\title{
Crossreactivity and Inheritance of Idiotypes Restricted to Human Anti-Tetanus Toxoid Antibodies
}

\author{
Celestyn M. K. Brozek and Raif S. Geha
}

Division of Allergy, The Children's Hospital, and the Department of Medicine, Harvard Medical School, Boston, Massachusetts 02115

\begin{abstract}
The presence of cross-reactive idiotypes on human IgG antibodies of tetanus toxoid (TT) antigen was assessed by examining the capacity of two anti-idiotypic (ID) antisera raised against IgG $\left(\text { Fab }^{\prime}\right)_{2}$ anti-TT (idiotype) from two subjects to bind radiolabeled "idiotype" and to inhibit the binding of radiolabeled TT to IgG from unrelated subjects and from family members of the idiotype donors. Idiotypic crossreactivity with unrelated individuals was infrequent and weak but was frequent and stronger among siblings. The strongest idiotypic crossreactivity was seen between identical twins in studies using four anti-ID raised against the anti-TT idiotypes of two sets of twins.

The results of the present study suggest that idiotypic determinants restricted to human anti-TT antibodies are, at least in part, encoded by inherited genes, which are infrequently shared among unrelated individuals.
\end{abstract}

\section{Introduction}

Human and mouse antibodies to self antigens have been reported to display a high incidence of cross-reactive idiotypes $(\mathrm{CRI})^{1}(1-$ 9). This could reflect the presence of conserved germ line $\mathrm{V}$ regions that encode variable regions that bind to self antigens. CRI have often been detected on antibodies to foreign antigens made in inbred mouse strains. In contrast, antibodies to most foreign protein antigens made by outbred animals express individual idiotypes, and rarely express CRI unless specifically induced with anti-idiotypic (anti-ID) antibodies (9-14). The data on the prevalence of CRI on antibodies made by unrelated human subjects in response to foreign antigens is conflicting (15-22).

In the present study we have examined the presence of CRI on human antibodies to tetanus toxoid (TT) using rabbit antiID antisera. These antisera were raised against idiotypes restricted to the anti-TT antibodies of single individuals. Two different assays were used to detect CRI: direct binding of radiolabeled IgG anti-TT antibodies by anti-ID and inhibition of TT binding to IgG anti-TT by anti-ID. Crossreactivity of idiotypes restricted to anti-TT antibodies was found to be infrequent and weak with unrelated subjects, significantly stronger and more frequent among siblings, and strongest among identical twins.

Address correspondence to Dr. Geha.

Received for publication 30 July 1986.

1. Abbreviations used in this paper: anti-ID, anti-idiotype; CRI, crossreactive idiotype; DT, diphtheria toxoid; TT, tetanus toxoid.

J. Clin. Invest.

(c) The American Society for Clinical Investigation, Inc. 0021-9738/87/04/1242/07 \$1.00

Volume 79, April 1987, 1242-1248

\section{Methods}

Antigens. TT and diphtheria toxoid (DT) antigens were obtained from Massachusetts Biological Laboratories (Jamaica Plain, MA) and fractionated over Sephadex G-200 columns. The second peak eluted from the column was used.

Antisera. Rabbit anti-human IgG serum was obtained from a rabbit immunized with human immune serum globulin. Fab-specific and Fcspecific rabbit antisera to human IgG were obtained from CalbiochemBehring Corp. (La Jolla, CA). Goat anti-rabbit IgG was produced by immunization with normal rabbit $\operatorname{lgG}$ and was extensively absorbed with normal pooled human IgG crosslinked to Sepharose 4-B before use.

Immunosorbents. Proteins were dialyzed against $0.1 \mathrm{M} \mathrm{NaHCO}_{3}$, pH 8.3, and crosslinked to cyanogen bromide-activated Sepharose 4-B beads (Pharmacia Fine Chemicals, Piscataway, NJ) at a ratio of 15-25 $\mathrm{mg}$ per $1 \mathrm{ml}$ packed beads, by following the instructions of the manufacturers.

Radioiodinations. Proteins were radiolabeled with ${ }^{125} \mathrm{I}$ by the chloramine $T$ method (23) to a specific activity of $2,000-3,000 \mathrm{cpm} / \mathrm{ng}$. TCA precipitability and the biological activity of the radiolabeled material exceeded $80 \%$ in each case.

Human sera, IgG immunosorbent purified antibodies, and pooled IgG. IgG was isolated over DEAE columns from the sera of subjects who had been recently immunized and boosted with TT (24). The IgG samples were centrifuged for $2 \mathrm{~h}$ at $100,000 \mathrm{~g}$ before use in the experiments to remove any immune complexes present. Immunosorbent purified antiTT and anti-DT IgG were isolated by passage of serum IgG over Sepharose 4-B columns crosslinked to the appropriate antigens and by subsequent elution of the bound material with $3 \mathrm{M} \mathrm{NaSCN}$.

Pooled human IgG was obtained from Massachusetts Biological Laboratories (Boston, MA) in the form of Cohn Fraction II prepared for intramuscular gammaglobulin therapy. For its use as an adsorbent, pooled IgG was thoroughly depleted of TT reactivity by exhaustive absorption by passage over TT-Sepharose. The reactivity-depleted IgG failed to agglutinate TT-coated red cells $(25)$ and contained no detectable $(<2$ $\mathrm{ng} / \mathrm{ml}$ ) IgG anti-TT as determined by radioimmunoassay (23).

Production of anti-TT "idiotypes." All anti-ID sera used in the present study were newly prepared and have not been reported previously. Two adult subjects aged 22 and $28 \mathrm{yr}$ with previous histories of immunization with TT and DT were boosted by intramuscular injection of 5 flocculation units of TT antigen (Massachusetts Biological Laboratories) and plasmapheresed at days 7 and 10 after immunization. These subjects are designated as subjects 1 and 2 in Tables I and II and in Figs. 1-4. IgG $\mathrm{F}\left(\mathrm{ab}^{\prime}\right)_{2}$ anti-TT was prepared from their plasma as described previously (22-24). Briefly, the plasma was clotted, precipitated with $50 \%\left(\mathrm{NH}_{4}\right)_{2} \mathrm{SO}_{4}$, and the precipitate was dissolved in normal saline, dialyzed against 0.01 $\mathrm{M}$ phosphate buffer, $\mathrm{pH} 6.8$, fractionated over a DEAE column, digested with pepsin with acetate buffer at $\mathrm{pH} 4.5$ (protein to enzyme ratio 50:1, $37^{\circ} \mathrm{C}, 48 \mathrm{~h}$ ), and passed over a G-150 column to obtain IgG $\mathrm{F}\left(\mathrm{ab}^{\prime}\right)_{2}$ fragments. This preparation was adsorbed against packed Staphylococcus aureus (IgG sorb; The Enzyme Center, Inc., Boston, MA) and did not show any reactivity by Ouchterlony analysis with rabbit antiserum specific for Fc of human IgG. The F(ab') IgG was passed over a Sepharose 4BTT column and the material that bound to the column was eluted with $3 \mathrm{M} \mathrm{NaSCN}$ and designated "idiotype." The material that did not bind to the column was further passed over Sepharose-TT until it was completely devoid of anti-TT activity as assessed by hemagglutination out of radioimmunoassay. This material was designated TT-nonreactive IgG $\mathrm{F}(\mathrm{ab})_{2}$, or "nonidiotype." 
A similar protocol was used to immunosorbent purify IgG $\left(\mathrm{Fab}^{\prime}\right)_{2}$ anti-DT over a Sepharose 4B-DT column.

Production of rabbit anti-ID IgG. Albino rabbits (Pine Acre Rabbitary, East Douglas, MA) were immunized with $0.5 \mathrm{mg}$ of $\mathrm{F}\left(\mathrm{ab}^{\prime}\right)_{2}$ anti-TT (idiotype) in $0.5 \mathrm{ml}$ of phosphate-buffered saline (PBS) emulsified in an equal volume of complete Freund's adjuvant (Difco Laboratories, Detroit, MI). Three booster immunizations with the same amount of the material in incomplete Freund's adjuvant were given at weekly intervals and the rabbits were bled $2 \mathrm{wk}$ after the last booster dose. The serum was separated from clotted blood and the IgG fraction was obtained by $50 \%\left(\mathrm{NH}_{4}\right)_{2} \mathrm{SO}_{4}$ precipitation. Preimmune and postimmune rabbit $\mathrm{IgG}(50-100 \mathrm{mg})$ was adsorbed on $1,000 \mathrm{mg}$ TT-nonreactive $\operatorname{IgG~F}\left(\mathrm{ab}^{\prime}\right)_{2}$ (coupled to Sepharose 4-B) from the idiotype donor and on 1,000 $\mathrm{mg}$ of pooled human immune serum globulin depleted of anti-TT activity. The adsorptions were repeated (usually two times) until the immune rabbit IgG showed no more crossreactivity with TT-nonreactive $\operatorname{IgG~} \mathrm{F}\left(\mathrm{ab}^{\prime}\right)_{2}$ derived from the idiotype donor as determined by radioimmunoassays. Furthermore, the rabbit IgG at $10 \mathrm{mg} / \mathrm{ml}$ contained no detectable anti-TT reactivity as determined by hemagglutination and by radioimmunoassay $(<2 \mathrm{ng} / \mathrm{ml})$.

Binding of radiolabeled $\operatorname{IgG~} F\left(a b^{\prime}\right)_{2}$ anti-TT and TT-nonreactive IgG $\left(\mathrm{Fab}^{\prime}\right)_{2}$ to rabbit anti-ID IgG. $100 \mu \mathrm{l}$ of ${ }^{125} \mathrm{I}-\mathrm{IgG} \mathrm{F}\left(\mathrm{ab}^{\prime}\right)_{2}$ anti-TT idiotype, or TT-nonreactive $\operatorname{IgG} F\left(\mathrm{ab}^{\prime}\right)_{2}$ nonidiotype $(\approx 100,000-200,000 \mathrm{cpm}$ and $50 \mathrm{ng}$ ), were mixed in Beckman microfuge tubes with different amounts of rabbit anti-ID IgG, rabbit preimmune IgG, or rabbit antihuman IgG (Fab specific) serum. After incubation at $37^{\circ} \mathrm{C}$ for $1 \mathrm{~h}$, normal rabbit IgG and goat anti-rabbit IgG were added in quantities to achieve a uniform content of total rabbit IgG in each tube and to achieve equivalence. The tubes were incubated at $37^{\circ} \mathrm{C}$ for an additional hour at $4^{\circ} \mathrm{C}$ overnight, then were centrifuged in a Beckman microfuge (13,000 rpm), the supernatants were discarded, and the formed precipitates were washed three times in washing buffer (PBS) containing $0.5 \%$ bovine serum albumin and $0.5 \%$ Tween-20). The radioactivity of the precipitates was counted in a gamma spectrometer (Model 1185; Tracor Analytic, Inc.; Elk Grove Village, IL). All determinations were made in triplicates and all experiments were done at least twice. In all calculations the background, i.e., number of counts obtained with the appropriate amount of rabbit preimmune IgG, was subtracted from the obtained values. The amount of ${ }^{125}$ I-idiotype precipitated by anti-ID IgG was expressed as a percentage of the amount of ${ }^{125} \mathrm{I}$-idiotype precipitated by rabbit antihuman Fab.

Inhibition of binding of radiolabeled IgG $F\left(a b^{\prime}\right)_{2}$ anti-TT to rabbit anti-ID IgG. Half a milligram of rabbit anti-ID IgG was incubated for $1 \mathrm{~h}$ at $37^{\circ} \mathrm{C}$ and $1 / 2 \mathrm{~h}$ at $4^{\circ} \mathrm{C}$ with different preparations of human IgG before adding ${ }^{125} \mathrm{I}-\mathrm{IgG} F\left(\mathrm{ab}^{\prime}\right)_{2}$ anti-TT. The rest of the experiment was performed as described above.

The inhibitory effect of TT and DT on ${ }^{125}$ I idiotype binding to antiID IgG was assessed by preincubating ${ }^{125}$ I-idiotype with TT or DT antigen for $1 \mathrm{~h}$ at $37^{\circ} \mathrm{C}$ and $1 / 2 \mathrm{~h}$ at $4^{\circ} \mathrm{C}$. The rest of the experiment was performed as just described. The percentage of inhibition of ${ }^{125}$ I-idiotype binding to IgG was calculated as:

\section{1 - (cpm bound by anti-ID IgG in the presence of inhibitor)/}

(cpm bound by anti-ID IgG without inhibitor) $\times 100$.

Inhibition of ${ }^{125} I-T T$ and ${ }^{125} I-D T$ binding to IgG by rabbit anti-ID sera. The dilution of human IgG necessary to precipitate $70 \%$ of the total amount of precipitable radiolabeled antigen was determined for each source of IgG from the following experiment. A set of Beckman tubes received $100 \mu$ l of serial dilutions of human IgG. Human myeloma IgG devoid of anti-TT or anti-DT activity was added to achieve a total amount of $30 \mu \mathrm{g}$ of IgG in each tube. Radiolabeled antigen $(100,000$ $200,000 \mathrm{cpm}$ and $50 \mathrm{ng}$ ) was added in $100-\mu \mathrm{l}$ vol for $1 \mathrm{~h}$ at $37^{\circ} \mathrm{C}$, rabbit anti-human IgG was added at equivalence, and the incubation was continued at $37^{\circ} \mathrm{C}$ for $1 \mathrm{~h}$, then at $4^{\circ} \mathrm{C}$ overnight. The tubes were then centrifuged in a Beckman microfuge and the formed precipitate were washed three times in washing buffer and counted in a gamma spectrometer as described above. The amount of $\operatorname{IgG}$ that bound $70 \%$ of the total amount of precipitable radiolabeled antigen was used in all further inhibition experiments.

The amount of IgG determined above was incubated without or with rabbit anti-ID IgG or with preimmune IgG for $1 \mathrm{~h}$ at $37^{\circ} \mathrm{C}$, after which radiolabeled antigen was added and the experiment was carried as described above. The background in this experiment was cpm bound by myeloma IgG alone, and it was subtracted before any calculations. Percent inhibition of binding was calculated:

\section{$1-\left(\mathrm{cpm}\right.$ of ${ }^{125} \mathrm{I}-\mathrm{TT} / \mathrm{DT}$ bound by IgG in the presence of inhibitor)/}

(cpm of ${ }^{125}$ I-TT/DT bound by IgG without inhibitor) $\times 100$.

Evaluation and calculation of crossreactivity. A significant crossreactivity was considered to be present when binding of $F\left(a b^{\prime}\right)_{2}$ anti-TT by anti-ID exceeded by threefold or more the binding of $\mathrm{F}\left(\mathrm{ab}^{\prime}\right)_{2}$ anti-DT from the same donor, and when inhibition by anti-ID of ${ }^{125}$ I-TT binding to IgG exceeded by threefold the inhibition of ${ }^{125}$ I-DT binding to IgG from the same donor. In each of the two assays used the degree of idiotypic crossreactivity between the idiotype donor and the test subject was calculated as:

$100 \times$ (specific reactivity of anti-ID with IgG of test subject)/

(specific reactivity of anti-ID with IgG of idiotype donor).

Statistical analysis. The statistical analysis was performed by the Student's $t$ test.

Family studies. Members from the families of subject 1 (family 1) and subject 2 (family 2 ) were all adults (>18 yr) and gave history of immunizations with TT. The last of those immunizations was always $>1 \frac{1}{2} \mathrm{yr}$ before the present study. IgG from those family members was obtained without prior boosting with TT.

Twin studies. Two sets of adult identical twins (age 22 and 32, respectively) were studied. They were boosted with TT and idiotype and rabbit anti-ID were prepared as described for donors 1 and 2 .

\section{Results}

Characteristics of the anti-ID antisera. The capacity of the two anti-ID antisera used in the present study to bind the $\operatorname{IgG}\left(\mathrm{F}\left(\mathrm{ab}^{\prime}\right)_{2}\right.$ anti-TT or idiotype used for immunization is shown in Fig. 1. $1 \mathrm{mg}$ of anti-ID IgG bound, respectively, 48 and $40 \%$ of ${ }^{125} \mathrm{I}$ idiotype but $<1 \%{ }^{125}$ I nonidiotype (TT-nonreactive IgG F $\left(\mathrm{ab}^{\prime}\right)_{2}$ ) derived from the donor of the anti-TT antibody used for immunization. Preimmune rabbit IgG bound $<1 \%$ of ${ }^{125}$ I the idiotype used for immunization (data not shown).

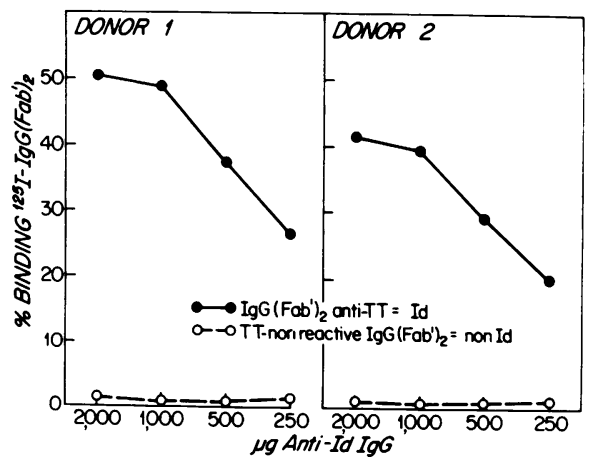

Figure 1. Idiotype binding by rabbit anti-ID IgG. Approximately 50 ng of ${ }^{125} \mathrm{I}$-labeled $\mathrm{IgG} F\left(\mathrm{ab}^{\prime}\right)_{2}$ anti-TT idiotype and of TT-nonreactive IgG $F\left(a b^{\prime}\right)_{2}$ nonidiotype were added to various amounts of rabbit antiIgG raised against the idiotype of the individual subject. The percent bound was calculated as the ratio of the precipitated by the anti-ID to the cpm precipitated by rabbit anti-human Fab $\times 100$. 


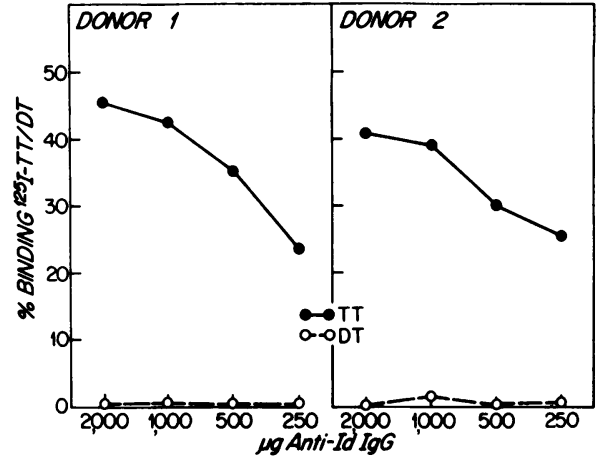

Figure 2. Inhibition of the binding of ${ }^{125}$ I-labeled TT and DT to IgG by rabbit anti-ID IgG raised against the IgG $\mathrm{F}\left(\mathrm{ab}^{\prime}\right)_{2}$ anti-TT (idiotype) of each of the two subjects. The cpm of ${ }^{125}$ I-TT precipitated in the absence of the inhibitor were $180,000 \mathrm{cpm}$ for subject 1 and 210,000 $\mathrm{cpm}$ for subject 2 . The $\mathrm{cpm}$ of ${ }^{125} \mathrm{I}-\mathrm{DT}$ precipitated in the absence of inhibitors were $30,000 \mathrm{cpm}$ for subject 1 and $60,000 \mathrm{cpm}$ for subject 2.

The capacity of the two anti-ID antisera used in the study to inhibit the binding of ${ }^{125} \mathrm{I}$-TT to IgG obtained from the idiotype donor is depicted in Fig. 2. When $1 \mathrm{mg}$ of anti-ID IgG was used this inhibition was 42 and $38 \%$, respectively, for the two donors studied. This inhibition was antigen specific because the anti-ID antisera did not inhibit binding of $\mathrm{IgG}$ from the two subjects studied to ${ }^{125}$ I-labeled DT ( $<5 \%$ inhibition). The inhibition of TT binding to IgG by anti-ID was not due to the presence of anti-TT antibodies in the rabbit antisera because these antisera contained no detectable anti-TT IgG $(<2 \mathrm{ng} / \mathrm{ml})$ and absorption of the anti-ID over TT-Sepharose did not alter its capacity to inhibit TT binding to human IgG.

The majority of the idiotypic determinants recognized by the two anti-ID antisera appeared to be closely related to the TT binding site because in each case TT antigen, but not DT antigen, inhibited the binding of anti-ID to ${ }^{125}$ I-labeled idiotype to an extent close to that obtained with cold idiotype (Fig. 3).

Cross-reactive idiotypes assessed by direct binding of idiotype to anti-ID. We directly examined the reactivity of each of the two anti-ID antisera with ${ }^{125}$ I-labeled IgG $\left(\mathrm{Fab}^{\prime}\right)_{2}$ anti-TT and $\operatorname{IgG}\left(\mathrm{Fab}^{\prime}\right)_{2}$ anti-DT obtained from 10 adult (18-42 yr) subjects

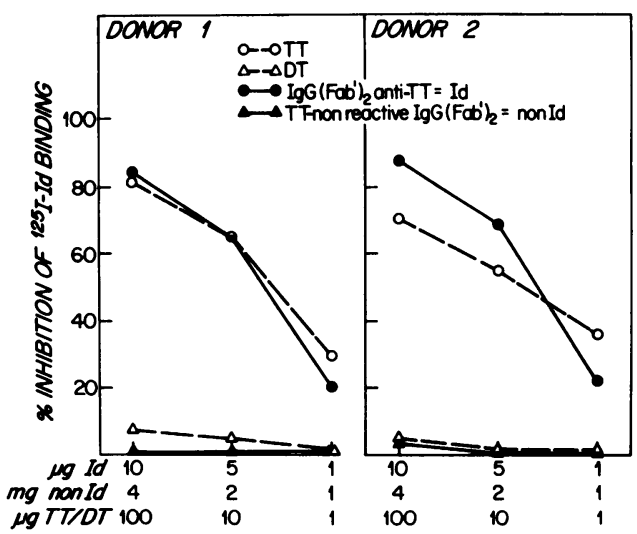

Figure 3. Inhibition of ${ }^{125}$ I-idiotype binding to anti-ID IgG $(500 \mu \mathrm{g})$ by idiotype (solid circles); TT (open circles), nonidiotype (solid triangles), and DT (open triangles). (subjects 3-12) unrelated to the two idiotype donors and from family members of the idiotype donors. None of the subjects was booster immunized with TT for at least $1 \frac{112}{\mathrm{yr}}$ before the study. Table I shows that in only four of 22 instances tested was there evidence of crossreactivity with unrelated subjects $(11,17$, 20 , and $25 \%$ ). There was no evidence of crossreactivity in this assay with two pools of human IgG tested (data not shown).

Table I. Anti-ID Binding to Radiolabeled Idiotypes from Different Subjects

\begin{tabular}{|c|c|c|c|c|c|}
\hline \multirow{3}{*}{$\begin{array}{l}\text { Source of } \\
\text { idiotype }\end{array}$} & \multirow{3}{*}{$\begin{array}{l}\text { Reactivity of } \\
\text { idiotype }\end{array}$} & \multicolumn{4}{|c|}{ Binding of idiotype by: } \\
\hline & & \multicolumn{2}{|c|}{ Anti-ID No. 1} & \multicolumn{2}{|c|}{ Anti-ID No. 2} \\
\hline & & Total & TT specific & Total & TT specific \\
\hline & & $\%$ & $\%$ & $\%$ & $\%$ \\
\hline \multirow[t]{2}{*}{ Subject 1} & TT & 40.2 & \multirow{2}{*}{36.1} & 5.3 & \multirow{2}{*}{2.7} \\
\hline & DT & 4.1 & & 2.6 & \\
\hline \multirow[t]{2}{*}{ Subject 2} & TT & 3.2 & \multirow{2}{*}{-0.8} & 38.7 & \multirow{2}{*}{35.7} \\
\hline & DT & 4.0 & & 3.0 & \\
\hline \multirow[t]{2}{*}{ Subject 3} & TT & 6.1 & \multirow{2}{*}{$\underline{4.1}(11)$} & 4.8 & \multirow{2}{*}{2.8} \\
\hline & DT & 2.0 & & 2.0 & \\
\hline \multirow[t]{2}{*}{ Subject 4} & TT & 6.1 & \multirow{2}{*}{2.2} & 5.8 & \multirow{2}{*}{1.8} \\
\hline & DT & 3.6 & & 3.8 & \\
\hline \multirow[t]{2}{*}{ Subject 5} & TT & 8.2 & \multirow{2}{*}{3.7} & 8.2 & \multirow{2}{*}{4.8} \\
\hline & DT & 4.5 & & 3.4 & \\
\hline \multirow[t]{2}{*}{ Subject 6} & TT & 6.5 & \multirow{2}{*}{2.8} & 10.5 & \multirow{2}{*}{$7.2(20$} \\
\hline & DT & 3.7 & & 3.3 & \\
\hline \multirow{2}{*}{ Subject 7} & TT & 4.8 & \multirow{2}{*}{2.3} & 8.2 & \multirow{2}{*}{4.8} \\
\hline & DT & 2.5 & & 3.4 & \\
\hline \multirow[t]{2}{*}{ Subject 8} & TT & 7.0 & \multirow{2}{*}{2.4} & 9.2 & \multirow{2}{*}{5.8} \\
\hline & DT & 4.6 & & 3.4 & \\
\hline \multirow[t]{2}{*}{ Subject 9} & TT & 13.4 & \multirow{2}{*}{$\underline{9.0}(25)$} & 9.8 & \multirow{2}{*}{4.4} \\
\hline & DT & 4.4 & & 5.4 & \\
\hline Subject 10 & TT & 6.4 & 12 & 10.6 & 4.0 \\
\hline & DT & 5.2 & & 5.6 & \\
\hline Subject 11 & TT & 7.9 & 46 & 8.9 & 49 \\
\hline & DT & 3.3 & 4.0 & 4.0 & 4.9 \\
\hline Subject 12 & TT & 9.5 & 37 & 9.1 & $61(17)$ \\
\hline & DT & 5.8 & 3.1 & 3.0 & \\
\hline
\end{tabular}

Equivalent amounts $(50 \mathrm{ng})$ of $\mathrm{F}\left(\mathrm{ab}^{\prime}\right)_{2}$ anti-TT and $\mathrm{F}\left(\mathrm{ab}^{\prime}\right)_{2}$ anti-DT ${ }^{125}$ I-labeled idiotypes were added to $1 \mathrm{mg}$ of rabbit anti-ID. The percentage bound idiotype was calculated as described in the legend of Fig. 1. All experiments were done in triplicate and the mean value is shown. Standard deviations were always $<16 \%$ of the mean values. Specific binding of anti-ID to IgG $F\left(a^{\prime}\right)_{2}$ anti-TT was obtained by subtraction of the binding of ${ }^{125}$ I-DT idiotype from that of ${ }^{125}$ I-TT idiotype. Values denoting significant crossreactivity, i.e., TT idiotype binding more than threefold DT idiotype binding, are underlined. Percent crossreactivity was calculated as described in the text, and is shown in between parentheses for individuals exhibiting significant crossreactivity. 
The capacity of each of the two anti-ID antisera to bind ${ }^{125} \mathrm{I}$ $\mathrm{F}\left(\mathrm{ab}^{\prime}\right)_{2}$ anti-TT derived from the immediate members of the family of the idiotype donors (donors 1 and 2) is shown in Table II. In the first family, the one parent available for study and three of four siblings showed significant idiotypic crossreactivity with the idiotype donor. In the second family, both parents and two of four siblings showed significant idiotypic crossreactivity with the idiotype donor.

Cross-reactive idiotypes assessed by the capacity of anti-ID to inhibit TT binding to IgG. We next examined idiotypic crossreactivity by studying the capacity of each of the anti-ID to inhibit the binding of ${ }^{125}$ I-radiolabeled TT antigen to IgG from 10 subjects unrelated to the two idiotype donors (subjects 3-12) and from the family members of the idiotype donors. The inhibition of DT binding to IgG was used as a control, was always $<5 \%$, and was subtracted from the value of inhibition of TT binding to IgG. The results of these experiments are shown in Fig. 4. The same four subjects who showed crossreactivity in the direct idiotype binding assay also showed crossreactivity in the inhibition of TT antigen binding assay, i.e., 4 of 22 instances. The pattern of crossreactivity was similar to that seen with the direct binding assay shown in Table IV, i.e., anti-ID No. 1 crossreacted with anti-TT antibodies from subjects 3 and 9 and anti-ID No. 2 crossreacted with anti-TT antibodies from subject No. 6 and No. 12 . This idiotypic crossreactivity was weak $(13,15,20$, and $21 \%$, respectively).

Among family members the same pattern of idiotypic crossreactivity seen with the idiotype binding assay was observed in the present assay, i.e., all parents and the same five (out of eight) siblings showed idiotypic crossreactivity with the two idiotype donors.

Table III summarizes the incidence of cross-reactive antiTT idiotypes based on our results with both the idiotype binding assay and the inhibition of antigen binding assay. In both assays

Table II. Anti-ID Binding to Radiolabeled Idiotypes from Family Members

\begin{tabular}{|c|c|c|c|c|c|}
\hline \multirow{2}{*}{$\begin{array}{l}\text { Source of } \\
\text { anti-ID }\end{array}$} & \multirow{2}{*}{$\begin{array}{l}\text { Source of } \\
\text { idiotypes }\end{array}$} & \multicolumn{3}{|c|}{ \% Binding by anti-ID of $\left.\mathrm{IgG}_{(\mathrm{Fab}}\right)_{2}$} & \multirow{2}{*}{$\begin{array}{l}\text { Cross- } \\
\text { reactivity }\end{array}$} \\
\hline & & Anti-TT & Anti-DT & TT specific & \\
\hline & & & & & $\%$ \\
\hline \multirow[t]{7}{*}{ Anti-ID 1} & Family 1 & & & & \\
\hline & Subject 1 & 40.2 & 4.1 & 36.1 & - \\
\hline & Mother & 20.2 & 4.7 & $\underline{15.5}$ & 43 \\
\hline & Sibling 1 & 20.4 & 6.2 & 14.2 & 39 \\
\hline & Sibling 2 & 11.3 & 2.3 & $\underline{9.0}$ & 25 \\
\hline & Sibling 3 & 10.2 & 4.7 & 5.5 & 11 \\
\hline & Sibling 4 & 14.5 & 3.6 & $\underline{11.1}$ & 30 \\
\hline \multirow[t]{8}{*}{ Anti-ID 2} & Family 2 & & & & \\
\hline & Subject 2 & 38.7 & 3.0 & 35.7 & - \\
\hline & Mother & 18.5 & 4.8 & 13.7 & 38 \\
\hline & Father & 12.0 & 3.3 & $\underline{8.7}$ & 24 \\
\hline & Sibling 1 & 8.1 & 4.5 & 3.6 & 10 \\
\hline & Sibling 2 & 13.8 & 3.7 & $\underline{10.1}$ & 28 \\
\hline & Sibling 3 & 7.2 & 4.2 & 3.0 & 8 \\
\hline & Sibling 4 & 19.5 & 5.1 & 14.4 & 40 \\
\hline
\end{tabular}

See legend to Table I.

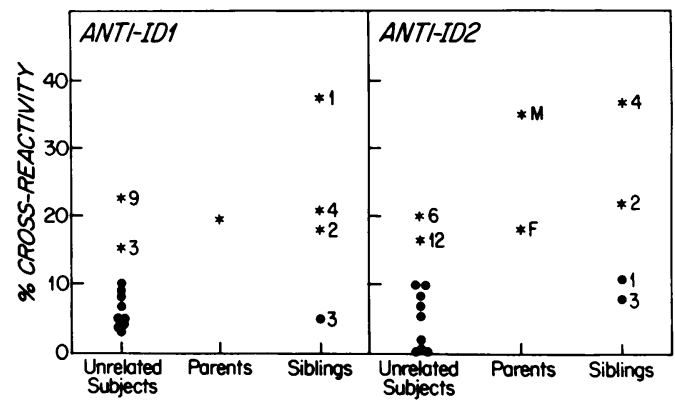

Figure 4. Specific inhibition by anti-ID $(1 \mathrm{mg})$ of the binding of ${ }^{125} \mathrm{I}-$ labeled TT to IgG from unrelated subjects and from family members. Specific inhibition was obtained by subtracting the percent inhibition of ${ }^{125}$ I-DT binding to anti-DT from the percent inhibition of ${ }^{125}$ I-TT binding to IgG anti-TT. All experiments were done in triplicate. Standard deviations were always within $18 \%$ of the mean value. Numbers refer to subject numbers (from Tables I and II). M, mother; F, father. Values showing significant crossreactivity are shown by asterisks.

crossreactivity was more prevalent and significantly $(P<0.05)$ more substantial with siblings than with unrelated subjects.

There was no correlation between idiotypic crossreactivity and sharing of HLA antigens within family members (data not shown). In both families the study of Inv and Gm allotypic markers was not informative.

CRI among identical twins. Two sets of genetically identical twins were studied for the presence of CRI on anti-TT antibodies. Individual rabbit anti-ID antisera were prepared against the antiTT idiotype from each member of the two sets of twins, i.e., four antisera were prepared. The results of tests for CRI are shown in Table IV. Mean idiotypic crossreactivity was $59 \pm 6 \%$ in the idiotype binding assay and $57 \pm 4 \%$ in the inhibition of TT binding assay. Idiotypic crossreactivity among identical twins significantly $(P<0.05)$ exceeded that seen among siblings of the two families we studied here. There was no crossreactivity between anti-ID No. 1 or anti-ID No. 2 with IgG anti-TT from twins A and B (data not shown).

\section{Discussion}

The data presented in this study indicate that IgG anti-TT antibodies from unrelated subjects exhibit infrequent and limited cross-idiotypic reactivity. In contrast, cross-idiotypic reactivity was more frequent and stronger among siblings and strongest among identical twins.

Table III. Crossreactivity among Unrelated Subjects vs. Siblings

\begin{tabular}{|c|c|c|c|c|}
\hline \multirow[b]{3}{*}{ Group } & \multicolumn{4}{|c|}{ Crossreactivity in: } \\
\hline & \multicolumn{2}{|c|}{ ID binding assay } & \multicolumn{2}{|c|}{$\begin{array}{l}\text { Inhibition of TT binding } \\
\text { assay }\end{array}$} \\
\hline & Incidence & $\begin{array}{l}\text { Cross- } \\
\text { reactivity }\end{array}$ & Incidence & $\begin{array}{l}\text { Cross- } \\
\text { reactivity }\end{array}$ \\
\hline & & $\%$ & & $\%$ \\
\hline Unrelated subjects & $4 / 22$ & $10.8 \pm 5.7$ & $4 / 22$ & $8.8 \pm 6.0$ \\
\hline Siblings & $5 / 8$ & $23.9 \pm 12.8$ & $5 / 8$ & $20.0 \pm 12.4$ \\
\hline
\end{tabular}


Table IV. Crossreactivity among Identical Twins

\begin{tabular}{|c|c|c|c|c|c|c|c|c|c|}
\hline \multirow{4}{*}{$\frac{\text { Family }}{\text { I }}$} & \multirow{4}{*}{$\begin{array}{l}\text { Twin } \\
\text { A }\end{array}$} & \multirow{2}{*}{\multicolumn{4}{|c|}{$\frac{\text { ID-specific binding assay }}{\%{ }^{125} \text { I-idiotype binding to: }}$}} & \multirow{2}{*}{\multicolumn{4}{|c|}{$\begin{array}{l}\text { Inhibition of TT binding assay } \\
\text { \% Specific inhibition by: }\end{array}$}} \\
\hline & & & & & & & & & \\
\hline & & \multicolumn{2}{|c|}{ Anti-ID-A } & \multicolumn{2}{|c|}{ Anti-ID-B } & \multicolumn{2}{|c|}{ Anti-ID-A } & \multicolumn{2}{|c|}{ Anti-ID-B } \\
\hline & & 38.4 & - & 25.3 & (56) & 36.5 & - & 22.4 & (55) \\
\hline & B & 23.1 & (61) & 45.3 & - & 18.9 & (52) & 40.4 & - \\
\hline \multirow[t]{2}{*}{ II } & A & 43.4 & - & 28.6 & (67) & 40.8 & - & 22.7 & (58) \\
\hline & B & 23.0 & (53) & 42.8 & - & 25.5 & (62) & 39.3 & - \\
\hline
\end{tabular}

See legend to Table I. Specific values for idiotype binding were obtained by subtracting the binding of ${ }^{125} \mathrm{I}-\mathrm{IgG}\left(\mathrm{Fab}^{\prime}\right)_{2}$ anti-DT $(<6 \%)$ from that of ${ }^{125} \mathrm{I}-\mathrm{IgG}\left(\mathrm{Fab}^{\prime}\right)_{2}$ anti-TT. Specific inhibition of TT binding was obtained after subtraction of the inhibition of ${ }^{125}$ I-DT binding $(<5 \%)$. Values in parentheses indicate percent crossreactivity.

The anti-ID antisera we have used were exhaustively absorbed against TT-nonreactive IgG obtained from the idiotype donor as well as from a pool of unrelated subjects. Thus, they were presumably directed against idiotypic determinants restricted to anti-TT antibodies. Thus, these anti-ID would lack reactivity against "framework" idiotypic determinants that could be shared by antibodies to TT and antibodies to other antigens. Our anti-ID antisera effectively inhibited the binding of TT antigen to IgG from the idiotype donor (Fig. 2). Also, TT antigen inhibited ID-anti-ID binding (Fig. 3), suggesting that the majority of the sites recognized by the anti-ID antisera were related to the antigen binding site. There was no evidence, however, that the anti-ID antisera contained antibodies bearing the "internal image" of TT antigen because, in the vast majority of the instances, the anti-ID antisera failed to compete with ${ }^{125}$ I-TT in binding to IgG anti-TT derived from unrelated subjects (Fig. 4) as well as from rabbits (data not shown). The lack of anti-ID antibodies bearing the internal image of TT did not simply result from denaturation of the TT binding site during the course of preparing the immunogen $\mathrm{IgG}\left(\mathrm{Fab}^{\prime}\right)_{2}$ anti-TT, because there was virtually complete recovery of TT binding activity in the immunizing idiotype fraction eluted from Sepharose TT column, compared with the starting IgG (data not shown).

It is important to note that in the present study the anti-ID antisera were absorbed with TT-nonreactive IgG obtained from the donor of the immunizing idiotype and from pooled IgG. Such absorptions would have removed potential CRI shared between anti-TT antibodies and antibodies of other specificity. The recognition by our anti-ID antisera only of idiotypic determinants restricted to TT and not of framework idiotypes, together with the absence from these antisera of anti-ID antibodies bearing the internal image of antigen, may have contributed to the relative infrequency in which CRI were detected in unrelated subjects. It is likely that the lack of CRI was related to the high degree of outbreeding among humans. In a highly outbred species like man it is not unexpected to find substantial differences in the TT binding polypeptide genes from unrelated individuals, which result from variable degrees of mutations and/or recombination events affecting the encoding $\mathrm{V}$ region genes. In this respect it is known that a substitution of one amino acid can result in major changes in the profile of idiotypic reactivity (26).
It is interesting to note that in the two assays for CRI used, the same pattern of crossreactivity was seen with the two antiID sera, which suggests that each anti-ID was recognizing separate CRI, each of which was present in 2 out of 11 unrelated subjects tested. The relative lack of CRI on human antibodies to the foreign antigen TT contrasts with the generally agreed upon observation of high incidence of CRI of human antibodies to self antigens (1-8). Based on the very strong homologies in the amino acid sequence analysis of the $v$ region polypeptides of many of these autoantibodies (27-29), it appears that autoantibodies are encoded for by germ line genes that remain highly conserved in the outbred individuals of the species.

Lack of CRI on antibodies to foreign antigens made by individuals of outbred species was evident in the early observations of Oudin and Michel on the idiotypes of antibodies made by outbred rabbits immunized with the bacterial antigens (10). More recently the idiotypes of murine antibodies to alprenolol have been found to generally lack CRI (14). The data on the frequency and extent of CRI antibodies to foreign antigens in humans is conflicting. Altevogt and Wigzell (15) found that a rabbit antiID antiserum raised against $\mathrm{IgG}\left(\mathrm{Fab}^{\prime}\right)_{2}$ anti-TT reacted with IgG from only one of four unrelated subjects. Natvig et al. (17) detected CRI on anti-Rh antibodies in only 2 of 22 subjects. More recently, Emmrich et al. (16) found CRI in antibodies to Streptococcus polysaccharide antigens from the majority of unrelated subjects, whereas Cheung et al. (18) demonstrated CRI on anti-casein antibodies of 12 out of 16 IgA-deficient patients. Bose et al. (20) detected CRI on antibodies to rye antigen in the majority of patients receiving rye antigen immunotherapy, and Kennedy et al. (19) detected CRI on antibodies to hepatitis B surface antigen in the majority of subjects. In the anti-TT system Saxon et al. (22) presented evidence for CRI at the T cell level in subjects repeatedly and vigorously immunized with TT antigen, whereas Hoffman et al. (21) demonstrated a high frequency of CRI present on a variable percentage (1-50\%) of anti-TT antibodies of unrelated subjects. The reasons for the conflicting results on the incidence of CRI to foreign antigens in human subjects are many. First, the nature of the antigen studied may be important. Caseins represent a family of small molecular weight $(12,000-24,000)$ proteins also present in man and potentially presenting a limited number of immunogenic determinants. Second, the immunization schedule used may predispose to the predominance of CRI as occurs in repeatedly immunized mice (30). In this respect, studies showing CRI in man have involved antibodies made in response to repeated immunizations, e.g., repeated injections of TT (22), or rye antigen (20); infection with a recurrent bacterium such as streptococcus (16) or with a replicating virus such as hepatitis B (19); and repeated injestion of the antigen casein (20). Third, the population of subjects studied may be important. The highest crossidiotypic reactivity of anti-casein antibodies occurred among IgA-deficient patients of Finnish descent, a group known to be genetically less heterogeneous than North Americans. Most importantly, two critical technical considerations previously alluded to may underlie the conflicting results obtained in the different studies on CRI in man. First, unless the anti-ID antisera are exhaustively absorbed they would contain antibodies to framework determinants, which may be represented on TT as well as non-TT binding antibodies. These determinants tend to be conserved among unrelated subjects. Second, the presence in the anti-ID antisera of anti-ID antibodies bearing the internal image 
of antigen will result in the detection of spurious CRI. In this respect, none of the studies demonstrating a high frequency of CRI in humans have examined the anti-ID reagents used for the presence of antibodies bearing the internal image of antigen (18-22).

Perhaps the most important observation of the present study is the high frequency and the strength of idiotypic reactivity among family members (Tables II and III, Fig. 4). Crossreactivity among family members is the more significant in view of two observations. First, it is known that the idiotypic profile of antiTT antibodies fluctuates during the course of the antibody response to TT (31). The effect of such fluctuations was however minimized in our study because none of the family members had been recently immunized with TT and because the idiotypes used to raise the anti-ID were taken 7-10 $\mathrm{d}$ after immunization and would have not been affected by the auto anti-ID-associated fluctuations in idiotypic profile (31). Second, the study of CRI among identical twins showed less than total cross-idiotypic reactivity (Table IV), which suggests that uninherited factors such as somatic mutations, differential use of various genes, and ID-anti-ID interactions may influence idiotype expression.

Inheritance of strain-specific idiotypes in mice is well known $(9,32,33)$. The inheritance of idiotypes in humans has been described for an individual rheumatoid factor idiotype (34). Our study suggests that this also occurs for idiotypes expressed on antibodies to a foreign antigen, such as TT. The exact interpretation of inherited CRI among family members is somewhat difficult in the absence of primary sequence data. Although in most cases serologically detected idiotypic crossreactivity has been found to be due to similar amino acid $\mathrm{v}$ region sequences, there have been exceptions in which it was found associated with homology of only a very small region, with homology of carbohydrate groups or with no sequence homology at all (35, 36). It seems unlikely, however, that similar variable regions as detected by our anti-ID antisera could be generated in family members exclusively by somatic diversification. The results, rather, suggest the inheritance of antibody genes related to the idiotypic determinants in humans. These genes appear not to be linked to those encoding HLA antigens. The lack, in the present study, of informative allotypic markers did not allow us to establish or to rule out linkage between genes encoding CRI and constant immunoglobulin chain genes.

\section{Acknowledgments}

The authors wish to thank Miss Melissa J. Smith and Mr. David Lence for secretarial assistance, and Ms. Nancy Wood for technical support.

This work was supported by U.S. Public Health Service grants AM31925, AI-21163, and AI-20373, and by a grant from the National Foundation. R. S. Geha is the recipient of an Allergic Diseases Academic Award (K07 AI-0440-02).

\section{References}

1. Kunkel, H. G., V. Agnello, F. G. Joslin, R. J. Winchester, and J. D. Capra. 1973. Cross idiotypic specificity among monoclonal IgM proteins with anti- $\gamma$-globulin activity. J. Exp. Med. 137:331-342.

2. Matsuyama, J., J. Fukumori, and H. Tanaka. 1983. Evidence of unique idiotypic determinants and similar idiotypic determinants on human antithyroglobulin antibodies. Clin. Exp. Immunol. 51:381-386.

3. Solomon, G., J. Schiffenbauer, H. D. Keiser, and B. Diamond.
1983. The use of monoclonal antibodies to identify shared idiotypes on human antibodies to native DNA from patients with lupus erythematosus. Proc. Natl. Acad. Sci. USA. 80:850.

4. Feizi, T., H. G. Kunkel, and D. Roelcke. 1974. Cross idiotypic specificity among cold agglutinins in relation to combining activity for blood group-related antigens. Clin. Exp. Immunol. 18:283.

5. Lefvert, A. J., R. W. James, C. Alloid, and B. W. Flupius. 1982. A monoclonal anti-idiotypic antibody against anti-receptor antibodies from myasthenic sera. Eur. J. Immunol. 12:790.

6. Shoenfeld, Y., D. A. Isenberg, J. Rauch, M. P. Madaio, B. D. Stollar, and R. S. Schwartz, 1983. Idiotypic cross reactions of monoclonal human lupus autoantibodies. J. Exp. Med. 158:718.

7. Vincent, A. 1981. Idiotype restriction in myasthenia gravis antibodies. Nature (Lond.). 290:293.

8. Eilat, D., R. Fischel, and A. Zlotnick. 1985. A central anti-DNA idiotype in human and murine SLE. Eur. J. Immunol. 4:368-375.

9. Weigert, M., and R. Riblet. 1978. The genetic control of antibody variable regions in the mouse. Springer Semin. Immunopathol. 1: 133.

10. Oudin, J., and M. Michel. 1969. Idiotypes of rabbit antibodies. I. Comparison of idiotypes of antibody against Salmonella typhi with that of antibodies against other bacteria in the same rabbits or antibodies against Salmonella typhi in various rabbits. J. Exp. Med. 130:595.

11. Wikler, H., J. D. Franssen, C. Collignon, O. Leo, B. Mariame, P. Van De Walle, D. De Groote, and J. Urbain. 1979. Idiotypic regulation of the immune system. Common idiotypic antibodies in rabbit. J. Exp. Med. 150:184.

12. Cazenave, P. A. 1977. Idiotypic-anti-idiotypic regulation of antibody synthesis in rabbits. Proc. Natl. Acad. Sci. USA. 74:5122.

13. Urbain, J., M. Wikler, J. D. Franssen, and C. Collignon. 1977. Idiotypic regulation of the immune system by induction of antibodies against anti-idiotypic antibodies. Proc. Natl. Acad. Sci. USA. 74:5126.

14. Chamat, S., J. Hoebeke, L. Emorine, J.-G. Guillet, and A. D. Strosberg. 1986. The immune response towards $\beta$-adrenergic ligands and their receptors. VI. Idiotypy of monoclonal anti-alprenolol antibodies. J. Immunol. 136:3805.

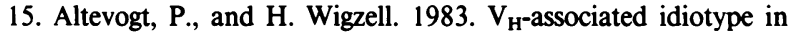
human anti-tetanus antibodies. Scand. J. Immunol. 17:183.

16. Emmrich, I., B. Greger, and K. Eichmann. 1983. A cross reactive human idiotype (B17) associated with antibodies to N-acetyl-D-Glucosamine specificity: immunoglobulin class association, and distribution in the population. Eur. J. Immunol. 13:273.

17. Natvig, J. B., H. G. Kunkel, R. E. Rosenfield, J. F. Dalton, and S. Kochwa. 1976. Idiotypic specificities of anti-Rh antibodies. J. Immunol. 116:1536.

18. Cheung, M. K. L., and C. Cunningham-Rundles. 1985. Crossreactive idiotypes in immunoglobulin A-deficient sera. J. Clin. Invest. 75:1722-1728.

19. Kennedy, R. C., and G. R. Dreesman. 1983. Common idiotypic determinant associated with human antibodies to hepatitis B surface antigen. J. Immunol. 130:385.

20. Bose, R., D. G. Marsh, J. Duchateau, A. H. Sehon, and G. Delespesse. 1984. Demonstration of auto-anti-idiotypic antibody cross-reacting with public idiotypic determinants in the serum of rye-sensitive allergic patients. J. Immunol. 135:2474.

21. Hoffman, W. L., P. D. Strucely, A. A. Jump, and J. D. Smiley. 1985. A restricted human antitetanus clonotype shares idiotypic crossreactivity with tetanus antibodies from most human donors and rabbits: reactivity with antibodies of widely differing electrophoretic mobility. $J$. Immunol. 135:3802.

22. Saxon, A., and E. Barnett. 1984. Human auto-antiidiotypes regulating T cell-mediated reactivity to tetanus toxoid. J. Clin. Invest. 73: 342-348.

23. Sonada, S., and M. Schlamowitz. 1970. Studies on ${ }^{125}$ I trace labeling of immunoglobulin G by chloramine-T. Immunochemistry. 7: 885. 
24. Geha, R. S. 1984. Idiotypic determinants on human T cells and modulation of human $\mathrm{T}$ cell responses by antiidiotypic antibodies. $J$. Immunol. 133:1846.

25. Gold, E. R., and H. H. Fundenberg. 1967. Chromic chloride: coupling reagent for passive hemagglutination reactions. J. Immunol. 99:859.

26. Radbruch, A., S. Zaiss, C. Kappen, M. Bruggemann, K. Beyreuther, and K. Rajewski. 1985. Drastic change in idiotype but not antigen binding specificity of autoantibodies by a single amino-acid substitution. Nature (Lond.). 315:506.

27. Kunkel, H. G. 1984. Cross-reacting idiotypes in the human system. In Biology of Idiotypes. M. Green and A. Nisonoff, editors. Plenum Publishing Corp., New York and London. 237-258.

28. Andrzejewski, C., J. Rauch, E. Laufer, B. D. Stollar, and R. S. Schwartz. 1980. Antigen-binding diversity and idiotypic cross-reactions among hybridoma autoantibodies to DNA. J. Immunol. 126:226.

29. Pons-Estel, B., F. Goni, A. Solomon, and B. Frangione. 1984. Sequence similarities among kIIIb chains of monoclonal human IgMk autoantibodies. J. Exp. Med. 160:893.

30. Conger, J. D., G. K. Lewis, and J. W. Goodman. 1981. Idiotype profile of an immune response. I. Contrasts in idiotypic dominance between primary and secondary responses and between IgM and IgG plaqueforming cells. J. Exp. Med. 17:173.

31. Geha, R. S. 1982. Detection of autoantiidiotypic antibody during the normal human immune response to tetanus toxoid antigen. $J$. Immunol. 129:139.

32. Eichmann, K., C. Berek. 1973. Mendelian segregation of a mouse antibody idiotype. Eur. J. Immunol. 3:599.

33. Nisonoff, A., S. T. Ju, and F. L. Owen. 1977. Studies of structure and immunosuppression of a cross reactive idiotype in strain A mice. Immunol. Rev. 34:89.

34. Pasquali, J.-L., S. Fong, C. Tsoukas, J. H. Vaughan, and D. A. Carson. 1980. Inheritance of immunoglobulin $\mathbf{M}$ rheumatoid-factor idiotypes. J. Clin. Invest. 66:863-866.

35. Clevinger, B., J. Schilling, L. Hood, and J. M. Davie. 1980. Structural correlations of cross-reactive and individual idiotypic determinants on murine antibodies to $(1 \rightarrow 3)$ dextran. J. Exp. Med. 151:1059.

36. Johnson, N., J. Slankard, L. Paul, and L. Hood. 1982. The complete $\mathrm{V}$ domain amino acid sequences of two myeloma inulin-binding proteins. Immunology. 128:302. 